DOI: 10.31866/2617-2674.4.2.2021.248702

UDC 778.534.4:791.62]:005

\title{
MANAGING STAGES OF FILM SOUND PRODUCTION
}

\section{Lev Riazantsevia , Yevheniia Yevdokymenko ${ }^{2 a}$}

${ }^{1}$ Honored Worker of Ukraine Culture, Associate Professor at the Cinema and Television

Arts Department; e-mail: I.ryazancev2016@gmail.com; ORCID: 0000-0003-1452-9602

${ }_{2}^{2}$ Master's Student at the Cinema and Television Arts Department; e-mail: evdokimenko.evgeniya2015@gmail.com; ORCID: 0000-0002-8053-5966

a Kyiv National University of Culture and Arts, Kyiv, Ukraine

Keywords:

sound;

sound producer;

film;

pre-production;

scoring;

post-production;

sound design,

soundtrack;

production;

dramaturgy

\begin{abstract}
The purpose of this article is to analyse the main stages of sound production in film. The study aims to establish the main principles of film sound design, prove the importance of a rational approach to each stage in the context of their impact on the results of the study, and determine the role of sound in film dramaturgy. The research methodology is based on theoretical methods, namely an analysis of information sources, comparison of Ukrainian and foreign approaches to filmmaking, generalisation and systematisation of practical knowledge and experience of sound production in film from the first sound film to the present day. Scientific novelty. The management structure of sound production's modern stages and their impact on creative and technical components of film soundtracks is analysed in detail for the first time. Conclusions. The article analyses the stages of sound production in film and establishes the main principles of sound design by studying Ukrainian and foreign approaches to creating sound in the film. The author summarises the rational approach to each stage in the context of their impact on the results of the study and examines the role of sound in film dramaturgy.
\end{abstract}

\section{For citation:}

Riazantsev, L. and Yevdokymenko, Y., 2021. Managing Stages of Film Sound Production. Bulletin of Kyiv National University of Culture and Arts. Series in Audiovisual Art and Production, 4(2), pp.244-251.

\section{Problem statement}

The emergence of sound in cinema revolutionised filmmaking. While the first films mostly included synchronous music and speech, over time it became obvious that sound can be a viable dramaturgical tool. As the result, the process of creating a film soundtrack became a multi-stage work with a distinctive structure. Understanding the nuances and rationally managing the stages of sound production in film is the key to successfully creating a soundtrack in a relatively short time with a planned budget. 


\section{Recent research and publications analysis}

A. Nisbett (1979) researched the development of film sound design during the film carrier era.

R. Viers (2012) and I. Barba (2016) described the experience of working on sound production stages in film.

L. Riazantsev $(2015 ; 2017)$ examined the synthesis of sound and image as well as the evolutionary features of sound in film.

A. Datsiuk (2020) described the sound design as a dramaturgical tool of a film.

\section{Main research material}

There are three main stages of film production: pre-production, production and post-production; or preparation, filming and editing of all components respectively. Nowadays, there are many experimental filmmakers with their personal approaches to film production. In order to achieve the desired results with minimal expenses, as time and budget play a significant role in filmmaking, it is important to pay attention to each of the stages and carefully think through every step. The sound design of a film is formed during the main stages. It aims to prepare quality musical arrangements and audio for the depiction.

It is worth noting that in order to maximise the efficiency of shooting, pre-production involves scouting. It is a process of examining environmental conditions, which is an important prerequisite for the most rational choice of suitable technical tools to implement an artistic intent.

Film crew members take part in exploring filming locations. However, in his textbook, 'A few words on audio engineering', I. Barba states that,

'The role of an audio engineer in the pre-production stage is not always un- derstood, so, in the best case, they get involved only 10-15 days before the production. Although audio engineers have to solve a great number of technical and technological issues during preproduction besides artistic matters such as casting the actors, choosing essential fragments of music, and compiling audio explication'. (Barba, 2012, p.5)

Moreover, audio recording quality on set is directly linked to whether the location facilitates it, that is why audio engineers should focus on how the location sounds. Each location is unique, but the requirement for quality sound remains. A solution can differ depending on the conditions: from a change of microphone placement to choosing a different filming location. It is important to be able to predict potential obstacles and be ready to change traditional, planned decisions. Pre-production helps to make choosing the set of instruments easier but it can never respond to all the requirements of the shooting process. Audio engineers should listen and think in the context of post-production regardless of whether the location is approved because some flaws can be successfully corrected using audio editing software. Furthermore, there is always an option of post-scoring and foley, but these methods are used as a last resort.

Studio post-scoring is technically more perfect but makes the sound material lose certain ease and naturalness present in a live recording. In 'Methodology of dubbing audio engineering and voiceover narration in film' L. Riazantsev emphasises that,

'given all technical advantages of studio post-scoring, something that is present in live recording disappears from the sound material'. The pecu- 
liarity of intonation, accidental slip of the tongue in an exciting scene, involuntary silence in a dramatic episode, i. e. the precious real-life roughness that actors, no matter how hard they try, cannot replicate as naturally at a studio. Moreover, in the process of 'laying out' the text during postscoring, non-synchronism of audio and image inevitably arises, which creates an additional feeling of artificiality'. (Riazantsev, 2017)

Foley mostly creates the objects' character because the actual sound does not always correspond to what is depicted.

Aside from its main technical task, audio scouting is also an opportunity for creative search. The best solutions arise from an unconventional perception of the environment. It means that on location it is important to not only constantly listen for the purpose of technical preparation, but also pay attention to, analyse and record environmental sounds because they can be used to make a unique artistic choice.

It should be noted that low-budget projects aiming to save costs involve the audio department directly during production. Thus, the shooting process often means struggling for the highest-quality raw material, which is why audio engineers should quickly respond to any situation and use all possible means to improve recording quality in given conditions (soundtracks, post-scoring on location etc.). It is important to, first, draw the line, as in post-production it is easier to correct sound than the image, and, second, to know all the technical capabilities of camera equipment and abide by all safety rules at all times.

In his study titled "A few words on audio engineering" I. Barba (2016, p.7) states that nowadays the number of film productions where preference on set is given to synchronised sound recording over guide tracks that require re-recording has drastically increased even for complex artistic directions. It is more cost-efficient since it allows to cut expenses in post-production at the post-scoring stage.

Therefore, optimized choice of equipment ensures quality synchronized audio recording on set. Depending on the recording technique, the sound department crew can only use external microphones for acoustically treated studios, or hidden lavalier microphones in combination with the external ones. In filmmaking, sound recording with only lavalier microphones is not in use, as its distinctive sound can break the emersion. On the other hand, such a method proved to be popular for creating Internet content.

Live recording technique involves using multitrack recorders, such as portable recorders, to capture sound in the form of pieces of audio on a recording medium contained in such a device. The recording is often copied to another medium, and the material is periodically combined and duplicated.

Quality microphone cables, headphones with flat frequency response, microphone accessories, tapes of different purposes, as well as good racks and cases are no less important. The full list of all the necessary equipment depends on the needs of the production under specific circumstances.

The sound department can consist of one person, a sound producer, who takes full responsibility for sound recording during production. This is a classic case for documentaries or live-action films, which are relatively small in an artistic context. Big projects are mostly characterised by bigger teams: a sound producer, boom operator, lavalier microphone operator, and an assistant. The number of people on the team as well as a list of 
their responsibilities varies depending on the tasks and the scale of production.

The finalised sound design of a film forms during post-production. The success depends on two major factors: the accuracy and clarity of a task for each type of work, and thought-through management for the sound department in general that encompasses both production and editing. The sound department accumulates material with post-production in mind. They assign a unique name to each audio file: a project name, a scene, shot or a take code, which must be voiced in the beginning or at the end of the recording. Soundtracks of atmospheric sounds, sound takes, and voice-overs should contain special indications and a description.

In his book titled 'Sound Studio. Audio techniques for Radio, Television, Film and Recording', A. Nisbett (1979, p.379) stated that the first stage of filmmaking in post-production is track selection. It is an analysis and evaluation of the sound recorded on set as well as determination of a part of the material that should be recreated in post-scoring.

The next step is creating a project using sound editing software with appropriate settings that correspond to the technical specifications of the video and audio material. An archive (.omf and .aaf file extensions) of synchronous pure sound is then added to the project, after which routing is created according to the structure.

Material processing starts after the project is prepared in the editing software, and the film is simultaneously sent to a synchronous sound recording studio. After the work is finished, the foley artist sends back the material in the form of a track archive, which is then added to the main film project. In small projects, synchronous sound recording often amounts to using appropriate soundtracks from a sound library. Such a method is perfectly acceptable, especially when the budget is relatively small.

Technical issues that regularly arise on set prevent recording lines in good quality. Sometimes, there is a need to highlight a character's distinctive characteristics by changing intonation, in which case sound engineers turn to post-scoring at a recording studio. However, in his book titled 'The location sound bible: How to record professional dialogue for film and TV', R. Viers (2012, p.181) states: 'Sometimes we have to record lines on set. With this aim finding a quiet and acoustically favourable place will suffice'. Such a method allows to somewhat reduce expenses in the editing stage. It is also important to consider that such material may have particular acoustic features typical for a certain facility.

The study demonstrated that sound broaching is a no less important process that takes place before audio mixing. Some sounds are recorded on set, while others come from commercial and personal libraries.

Music production and sound design are two separate processes. They take up an irregular share of post-production but have their own deadlines. Artistic sound solutions sometimes exist before the film is produced. They can also arise during production or at the very end of the process. Sound design is one of the most powerful means of conveying dramaturgy. In his work titled 'Sound synthesis and language functions in film' L. Riazantsev studied the evolution of sound capabilities in filmmaking:

'Adding an auditory element to visuals enhances the expressiveness of the whole because the content is conveyed by two different kinds of expressive means and at the same 
time reaches the audience through two different sensory organs. Hence, the third quality that arises from the relations of two components and often becomes the holder of the true artistic expression because it constitutes a real comment to the two interacting factors.' (Riazantsev, 2015)

Thus, sound design is not only about art but also a high level of technical knowledge. It is a constant creative search that requires an audio engineer to make creative decisions using both analogue and digital tools.

In his work titled 'The location sound bible: How to record professional dialogue for film and TV' R. Viers (2012, p.192) assures that the secret of sound design lies in raw material. The author stresses that the ambience of a film depends on the quality of the recorded foley and the variety of its sound. The more recording options there are the greater opportunities for experimenting.

It should also be noted that creating an ambience of the picture involves accurately feeling the mood, form, texture and substance of what is depicted. Artistic choice can be based on using tonal music elements, as the composer, H. Zimmer did in 'Dunkirk' (2017, dir. Ch. Nolan), where he created an integral continuous sound canvas, which is simply transforming during the whole film depending on what is happening. It would not have worked if such choices had been perceived as a fullfledged musical accompaniment during the whole film. Nevertheless, the evolution of correlation between sound and image led to using musical elements more sparingly to highlight and accentuate their significance for dramaturgy as a whole.

'Atlantis' (2019, dir. V. Vasianovych) is the complete opposite. In the article titled 'This is Serhii Stepanskyi and he creates sound for the biggest Ukrainian films' A. Datsiuk states that

'Art direction has little dialogue but a lot of static and production noises that create the sound palette of the film. The future, which resonates painfully with the present day, received its distinctive sound thanks to sound engineer S. Stepanskyi. His work almost received an award for the best soundtrack at the French Les Arcs Film Festival. Only later did the jury learn that the film did not have a composer and therefore there was no classical musical accompaniment.' (Datsiuk, 2020)

In fact, music in 'Atlantis' only plays once, as an intra-frame sound, in a scene at a factory during the showing of 'The Symphony of Donbas' (dir. Dzyga Vertov, 1931). Thus, S. Stepanskyi effectively created a distinct voice for each scene by layering foley elements. However, contrastive dynamic action creates the impression that the film does have musical accompaniment.

The key step in post-production is re-recording, i. e. compiling all the audio material in one project and creating the final mix in compliance with technical requirements. A large amount of material is accumulated in the editing stage. In the process of re-recording, when the soundtracks are directly compared with each other and the visuals, it is possible to, first, decide on the ratio of sound effects in a film in accordance with dramaturgy (noise, music, silence, lines), and, second, to eliminate all the possible technical flaws from the final mix.

\section{Conclusions}

Creating the ambience of the picture involves accurately feeling the mood, form, 
texture and substance of what is depicted. Artistic choice can be based on using tonal music elements or foley, as in 'Dunkirk' (2017, dir. Ch. Nolan) and 'Atlantis' (2019, dir. V. Vasianovych).

Film influences human consciousness the most, as imagery exists in two dimensions at the same time - visual and auditory. Prevalence of one over the other is either a feature of some narrow genres or the absence of complex audio-visual solutions. It is the synthesis of image and sound that creates a complex impression from the picture.

Sound design is formed during the whole time of production. And sometimes the idea exists before the film is produced, arises in the process, or emerges from the groundwork at the end. All the stages are closely interconnected while having distinct features. Preparedness for filming, or pre-production, affects the quality of material gathered during production, which in turn will affect the result of post-production. Knowing the nuances of the work and rationally managing the stages of sound production in the film is the key to successfully creating a soundtrack in a relatively short time with a planned budget.

\section{REFERENCES}

Barba, I.D., 2016. Neskolko slov o zvukorezhissure [A few words about sound engineering]. In: A.B. Ananev, ed. Zapis zvuka na semochnoi ploshchadke [Sound recording on the seedbed]. Kyiv: Kyiv National University of Culture and Arts. Ch. 7.

Datsiuk, A., 2020. Znaiomtes: tse Serhii Stepanskyi, i vin stvoriuie zvuk dlia holovnykh ukrainskykh filmiv [Meet: this is Serhiy Stepansky, and he creates sound for the main Ukrainian films]. DTF Magazine, [online] 18 November 2020. Available at: <https://donttakefake.com/ serhiy-stepanskyi-interview/> [Accessed 20 November 2020].

Nisbett, A., 1979. Zvukovaia studiia. Tekhnika i metody ispolzovaniia [Sound Studio. Technique and methods of use]. Translated from English by B.G. Collender. Moscow: Sviaz.

Riazantsev, L.V., 2015. Syntez zvuku i zobrazhennia ta funktsii movy u filmi [Synthesis of sound and image and language functions in film]. Kultura i mystetstvo u suchasnomu sviti, 16, pp.177-184.

Riazantsev, L.V., 2017. Metodolohiia zvukorezhysury dubliazhu ta zakadrovoho ozvuchennia filmiv. In: Kulturne mystetske seredovyshche: tvorchist ta tekhnolohii [Cultural and artistic environment: creativity and technology]. Proceedings of the international scientific and creative conference. Kyiv, Ukraine, 20 April 2017. Kyiv, pp.130-134.

Viers, R., 2012. The Location Sound Bible: How to Record Professional Dialog for Film and TV. Los Angeles: Michael Wiese Productions. 


\title{
МЕНЕДЖМЕНТ ЕТАПІВ ВИРОБНИЦТВА ЗВУКУ В КІНО
}

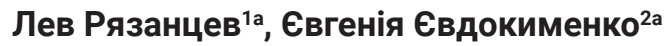 \\ 1 заслужений працівник культури України, доцент кафедри кіно-, телемистецтва; \\ e-mail: I.ryazancev2016@gmail.com; ORCID: 0000-0003-1452-9602 \\ 2 магістрант кафедри кіно-, телемистецтва; \\ e-mail: evdokimenko.evgeniya2015@gmail.com; ORCID: 0000-0002-8053-5966 \\ а Київський національний університет культури і мистецтв, Київ, Україна
}

\begin{abstract}
Анотація
Мета дослідження - проаналізувати основні етапи виробництва звуку в кіно; встановити основні принципи формування звукового оформлення фільму; довести важливість раціонального підходу до кожного етапу в контексті їх впливу на кінцевий результат роботи; дослідити роль звуку в драматургії фільму. Методологія дослідження заснована на теоретичному аналізі інформаційних джерел; порівнянні вітчизняних та закордонних підходів до створення фільмів; узагальненні та систематизації практичних знань і досвіду виробництва звуку в кіно від першого звукового фільму до сьогодення. Наукова новизна. Вперше детально проаналізовано структуру менеджменту сучасних етапів виробництва звуку та їх вплив на творчу й технічну складові формування звукового супроводу фільму. Висновки. У статті проаналізовано основні етапи виробництва звуку в кіно. За допомогою аналізу вітчизняних та закордонних підходів до створення звуку в кіно встановлено основні принципи формування звукового оформлення фільму. Узагальнено способи раціонального підходу до кожного етапу в контексті їх впливу на кінцевий результат роботи. Досліджено роль звуку в драматургії фільму.
\end{abstract}

Ключові слова: звук; звукорежисер; кіно; препродакшн; продакшн; постпродакшн; саунд-дизайн; саундтрек; виробництво; драматургія 


\title{
МЕНЕДЖМЕНТ ЭТАПОВ ПРОИЗВОДСТВА ЗВУКА В КИНО
}

\author{
Лев Рязанцев ${ }^{1 a}$, Евгения Евдокименко ${ }^{2 a}$ \\ 1 заслуженный работник культуры Украины, доцент кафедры кино-, телеискусства; \\ e-mail: I.ryazancev2016@gmail.com; ORCID: 0000-0003-1452-9602 \\ ${ }^{2}$ магистрант кафедры кино-, телеискусства; \\ e-mail: evdokimenko.evgeniya2015@gmail.com; ORCID: 0000-0002-8053-5966 \\ а Киевский национальный университет культуры и искусств, Киев, Украина
}

\begin{abstract}
Аннотация
Цель исследования - проанализировать этапы производства звука в кино; установить основные принципы формирования звукового оформления фильма; доказать важность рационального подхода к каждому этапу в контексте их влияния на конечный результат работы; исследовать роль звука в драматургии фильма. Методология исследования основана на теоретическом анализе информационных источников; сравнении отечественных и зарубежных подходов к созданию фильмов; обобщении и систематизации практических знаний и опыта производства звука в кино от первого звукового фильма до современности. Научная новизна. Впервые подробно проанализирована структура менеджмента современных этапов производства звука с их влиянием на творческую и техническую составляющие формирования звукового сопровождения фильма. Выводы. В статье проанализированы основные этапы производства звука в кино. С помощью анализа отечественных и зарубежных подходов к созданию звука в кино установлены основные принципы формирования звукового оформления фильма. Обобщены способы рационального подхода к каждому этапу в контексте их влияния на конечный результат работы. Исследована роль звука в драматургии фильма.
\end{abstract}

Ключевые слова: звук; звукорежиссер; кино; препродакшн; продакшн; постпродакшн; саунд-дизайн; саундтрек; производство; драматургия 